\title{
HUMAN-WILD MAMMAL CONFLICT IN A HUMAN DOMINATED MIDHILL LANDSCAPE: A CASE STUDY FROM PANCHASE AREA IN CHITWAN ANNAPURNA LANDSCAPE, NEPAL
}

\author{
Jagan Nath Adhikari ${ }^{1,2}$, Bishnu Prasad Bhattarai ${ }^{1 *}$, Tej Bahadur Thapa ${ }^{1}$ \\ ${ }^{I}$ Central Department of Zoology, Tribhuvan University, Kirtipur, Kathmandu, Nepal \\ ${ }^{2}$ Department of Zoology, Birendra Multiple Campus, Tribhuvan University, Chitwan \\ *Corresponding author: bpbhattarai@cdztu.edu.np; bhattaraibp@gmail.com
}

(Received: September 11, 2018; Revised: December 6, 2018; Accepted: December 8, 2018)

\begin{abstract}
Issues of human wildlife conflict (HWC) always challenges in conservation and management. Crop raiding, property damage, livestock depredation and human casualties are the most common forms of conflict. It was investigated the issues of human wild mammal conflict in and around the Panchase area in Chitwan Annapurna Landscape of Nepal from March 2017 to April 2018 using semi-structured questionnaires and focal group discussion. Wide spread human wildlife conflict was observed in Panchase area. Monkey, muntjac deer, porcupine and rabbit were the main crop raider that resulted in total economic loss of US\$29.56 per household (HH). Overall economic loss by livestock depredation was estimated US\$11254.54 (US\$ 112.54/HH). Leopard contributed to the highest cases of livestock depredation. A total of five human attack cases were recorded including one fatal and four injuries. Himalayan black bear contributed to $80 \%$ of the total attacks and $20 \%$ by leopards. Present study focused on the issues and status of conflicts in the Panchase area, a representative of midhills and Chitwan Annapurana Landscape. This study suggests that future study related to mitigation and preventing methods should be conducted to minimize the issues of human wildlife conflicts.
\end{abstract}

Keywords: Human wildlife conflict, Panchase, Livestock depredation, Household, Leopard

\section{INTRODUCTION}

The history of human wildlife conflict (HWC) is as old as the existence of human beings on the earth. HWC is a common phenomenon from the past and has become a significant problem throughout the world (Redpath et al. 2015). Most common forms of conflicts with wildlife are crop raiding, property damage, livestock depredation and human casualties (Ogutu et al. 2014). Human casualties and livestock depredation are the most serious nature of conflict among all. The major governing factors of habitat loss, degradation and fragmentation through human activities are animal husbandry, agricultural expansion, exploitation of natural resources and developmental activities (Fernando et al. 2005). Most of the developed and developing countries are facing the issues of HWC (Ogutu et al. 2014). However, it is more in developing countries than developed countries as the rural population of developing countries depend upon the animal husbandry and crop for their livelihoods (Cromsigt $e t$ al. 2013). HWC results in negative impact on human or their resources and wildlife or their natural habitat and it carries great threats to the survival of many wildlife species (Madden \& McQuinn 2014, Amaja et al. 2016). Crop and property damage, livestock depredation, and human injury and casualty are common effects of HWC resulting in huge economic losses that make people to migrate from wildlife-conflict areas to non-conflict areas. HWCs also bring numerous social, economic and ecological consequences (Messmer 2009). The number and type of damage caused by wildlife varies according to the species, the time of year, and the availability of natural prey and crop raiding species (Mwamidi et al. 2018).

In Nepal, HWC is a major problem in most of the protected areas and national forests or even in the community forest areas (Lamsal 2012). The frequency and intensity of HWC in Nepal mostly arise from crop damage, livestock depredation, human injuries and casualties caused by wildlife, illegal logging, livestock grazing, fodder collection, medicinal plant collections, poaching and poor relations between local people and protection units (Lamsal 2012, Lamichhane et al. 2018). The main wildlife species involve in the HWC in the lowland of central Himalaya (e.g., in the buffer zones and surrounding areas of the Chitwan National Park) are the large mammals such as Asian elephant (Elephas maximus Linnaeus, 1758 ), one-horned rhinoceros (Rhinoceros unicornis Linnaeus, 1758), wild boar (Sus scrofa Linnaeus, 1758) and Bengal tiger (Panthera tigris Linnaeus, 1758) (Dhungana et al. 2016, Lamichhane et al. 2018). Crop depredation by monkeys, muntjac deer, wild boar, Himalayan black bear, livestock depredation by common leopard and human injuries and casualties by leopard and Himalayan black bear is considered to be the most ubiquitous form of conflict in mid-hills of Nepal (Dhungana et al. 2016).

Most of the study about human wildlife conflicts was focused in and around the protected areas. The government and even the researcher give more priorities 
in protected areas than national forest and community forest areas. People in mid-hills are also facing the problems of HWCs. The extant of human wildlife conflict is mainly caused by wild mammals in many parts of Nepal including Terai, mid-hills and high mountain areas. Hence, this study was focused on the human wild mammal conflicts (HWMC) in the Panchase area, a representative landscape in Chitwan Annapurna Landscape. This paper analyzed the data on humanwildlife conflicts collected from the field within the duration of one year (2017April to 2018 June) via questionnaires, focal group discussion and key informant interview. The objectives of this study are to (1) explore the crop raiding and damage by herbivores, (2) determine the livestock depredation, (3) identify the human injury and casualties, and (4) determine the human wild mammal conflict hotspots. Such information provides the guidelines for the conservation and management of the forest outside the protected areas and helps to minimize the conflicts issues in and around Panchase area.

\section{MATERIALS AND METHODS}

\section{Study area}

Panchase protected forest area (PPF) is rich in biodiversity and has high biodiversity value in the region as depicted in Fig. 1. The Panchase area $\left(27.91 \mathrm{~km}^{2}\right)$ covers some parts of Pokhara-Lekhnath Metropolitan city and Annapurna rural municipality of Kaski, Kushma municipality and Modi rural municipality of Parbat district and Adhikhola rural municipality of Syangja district (Bhattarai et al. 2011). The PPF has been declared as a 'Protected Forest', under the article 23 of the Forest Act 2002 by recognizing its rich biodiversity, forest resources as well as cultural and spiritual values on 27 February 2011(Baral et al. 2017). The mean maximum and minimum temperature of PPF area are $29^{\circ} \mathrm{C}$ and 5.3 ${ }^{\circ} \mathrm{C}$, respectively. The coldest month is January with the minimum temperature $4{ }^{\circ} \mathrm{C}$ or below. On average, Panchase area receives $3883 \mathrm{~mm}$ of rainfall every year (Park \& Alam 2015, Adhikari et al. 2018a).

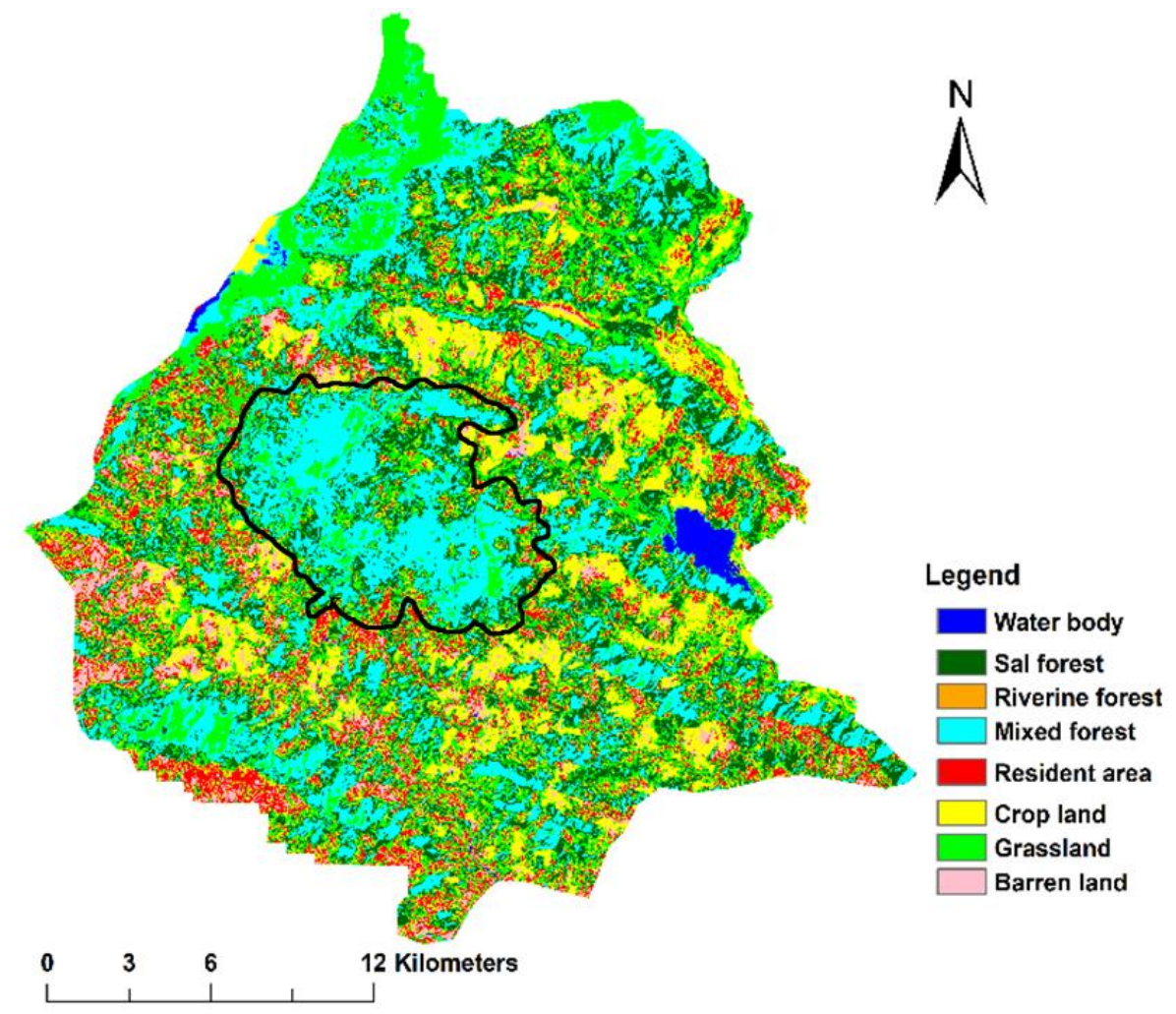

Fig. 1. Map of study area showing Panchase Protected Forest (highlighted area) and adjoining areas

The terrestrial ecosystem of PPF and its slopes on all directions consists of different land use types such as forest grazing and agricultural land. Human settlements in the area are located in the sloppy hills and valleys. Forest starts from $1,450 \mathrm{~m}$ to $2,517 \mathrm{~m}$ altitude with sub-tropical to temperate mixed evergreen forest. Rhododendron and oak were the dominant species in the forests which is now replaced by Rakchan (Daphniphyllum himalense), which indicates the degraded condition of the forest (Màren et al. 2014, Thapa 2014). Panchase is the home of reported 589 flowering plant species including 94 orchid species, 24 mammal species and 260 bird species (Adhikari et al. 2017, Baral et al. 2017). Major villages around Panchase area are Sidhane, Bhanjyang, Pumdi Bhumdi, Arthar Dada Kharka, Bhadaure Tamagi, Damdame and Virmathi. The main income sources of the villagers are agriculture, 
animal husbandry, tourism and remittance. In terms of demographic distribution, Gurung are the most dominant ethnic group in Kaski and Parbat districts, while the population of Brahmin and Chhetri are more in Syangja district.

\section{Study design}

Based on preliminary survey (March-April, 2017), major resident areas in and around the Panchase such as Sidhane (Kaski), Bhanjyang (Kaski), Pumdi Bhumdi (Kaski), Bhadaure and Tamagi (Kaski), Virmathi and Daumdame (Kaski), Arthar dada and Kaule (Parbat), Chitre (Parbat) and Wangsing (Syangja) were purposively selected because of the presence of serious HWMC in the areas. The respondents in these areas were selected using stratified random sampling regarding their age, sex, cast occupation and education status.

\section{Data collection}

A total of 100 respondents (25 from Sidhane, 8 from Bhanjyang, 12 from Pumdi Bhumdi, 20 from Bhadaure and Tamagi, 6 from Virmathi and Daumdame, 13 Arthar dada and Kaule, 8 from Chitre and 8 from Wangsing) were sampled by using the semi structured questionnaires related to crop damage, livestock depredation and human casualty and injury. The selected area and house hold were categorized into three groups based on their proximity towards the forest edge as near $(<0.5 \mathrm{~km})$, medium distance $(0.5-1 \mathrm{~km})$ and far $(>1 \mathrm{~km})$. The questionnaire was translated into Nepali language by interviewers. In general, male are the head of the family in Nepal and hence most of the respondents involved in this sampling were male than female (Male $=66$, Female $=34)$. The detail of the demographic profile of the respondents is listed in Table 1 . The focus group discussion, informal interview, key informant interview (local healers, community leaders, teachers) were performed during the field study for the verification and further information. Information on human casualties, cattle depredation and crop damage by the large mammals was collected from the forest department, field staffs and villagers. The compensation paid for various casualties and injuries were collected from district forest office for the validity of the data.

Table 1. Demographic profile of the respondents in Panchase area

\begin{tabular}{|c|c|c|c|c|}
\hline Respondents features & Categories & Scoring Method & Number of Respondents & Summary \\
\hline \multirow{5}{*}{ Age } & $30-40$ & \multirow{5}{*}{ Years } & 14 & \multirow{5}{*}{$\begin{array}{l}\text { Mean }=20 \\
S D=16.01 \\
S E=7.16\end{array}$} \\
\hline & $41-50$ & & 36 & \\
\hline & $51-60$ & & 38 & \\
\hline & $61-70$ & & 9 & \\
\hline & 70 above & & 3 & \\
\hline \multirow{5}{*}{ Occupation } & Farmer & \multirow{5}{*}{ Number } & 52 & \multirow{5}{*}{$\begin{array}{l}\text { Mean }=20 \\
S D=18.85 \\
S E=8.43\end{array}$} \\
\hline & Teacher & & 8 & \\
\hline & Social workers & & 11 & \\
\hline & Government Employer & & 7 & \\
\hline & Business & & 22 & \\
\hline \multirow{2}{*}{ Gender } & Female & \multirow{2}{*}{ Number } & 34 & \multirow{2}{*}{$\begin{array}{l}\text { Mean }=50 \\
\mathrm{SD}=22.62 \\
\mathrm{SE}=16\end{array}$} \\
\hline & Male & & 66 & \\
\hline \multirow{5}{*}{ Education status } & Illiterate & \multirow{5}{*}{$\begin{array}{c}\text { Year of } \\
\text { schooling }\end{array}$} & 9 & \multirow{5}{*}{$\begin{array}{l}\text { Mean }=20 \\
S D=13.50 \\
S E=6.04\end{array}$} \\
\hline & Literate & & 38 & \\
\hline & Secondary & & 31 & \\
\hline & Intermediate & & 12 & \\
\hline & University & & 10 & \\
\hline \multirow{5}{*}{ Caste system } & Dalit & \multirow{5}{*}{ Number } & 24 & \multirow{5}{*}{$\begin{array}{l}\text { Mean }=20 \\
S D=23.44 \\
S E=10.48\end{array}$} \\
\hline & Gurung & & 59 & \\
\hline & Magar & & 2 & \\
\hline & Brahmin/Chhetri & & 11 & \\
\hline & Gharti & & 4 & \\
\hline
\end{tabular}

\section{Data analysis}

Estimation of economic loss due to crop damage may lead to biased results, especially in the comparative studies as the economic value of such assets depend on many site and species - specific factors. As there is a general tendency of villagers and victims to expand the loss (Upreti 1985). Total loss of a given crop was calculated using the following equation (1).

$$
\mathrm{Li}=\mathrm{Ai} \times \mathrm{Yi}
$$


Where, $\mathrm{Li}=$ Loss of a given crop $(\mathrm{kg} / \mathrm{year})$ incurred by household $\mathrm{i}, \mathrm{Ai}=$ Area damaged by elephant as reported by household $\mathrm{i}$ and $\mathrm{Yi}=$ Average yield in $(\mathrm{kg} / \mathrm{year} / \mathrm{unit}$ area) for a given crop as reported by household $i$.

The monetary value of the total crop damage was calculated by multiplying the total loss of a given crop with the unit farm get price of the crop. The farm get price of the different crops was determined by calculating mean price indicated by district agriculture office and local market price. The tentative price of different vegetables (reddish, pea, cabbage, cauliflower, tomato, bean, carrot, pumpkin, squash fruit, bottle gourd, sponge gourd, snake gourd and cucumber) grown mainly in their home gardens are listed in Table 2.

Table 2. Farm get price of the crops in 2018 April (Price in $\mathbf{N R s} / \mathbf{K g}$ )

\begin{tabular}{|l|c|c|c|}
\hline Crops & $\begin{array}{c}\text { District } \\
\text { Agriculture } \\
\text { Office }\end{array}$ & $\begin{array}{c}\text { Market } \\
\text { Price }\end{array}$ & $\begin{array}{c}\text { Farm Get } \\
\text { Price }\end{array}$ \\
\hline Paddy & 25 & 30 & 27.5 \\
\hline Wheat & 25 & 27 & 26 \\
\hline Millet & 30 & 32 & 31 \\
\hline Oat & 30 & 38 & 34 \\
\hline Maize & 20 & 25 & 22.5 \\
\hline Potato & 25 & 35 & 30 \\
\hline Vegetable & 40 & 50 & 45 \\
\hline
\end{tabular}

The data obtained from questionnaire survey were analyzed by descriptive statistics, regression analysis and presented in charts and tables. The price rate of the cattle, buffaloes, sheep or goat was estimated by calculating the mean price of district veterinary office and nearest local market. Market prices of livestock were obtained from local people during interview and also verified with the nearest local market. Cow, ox and buffalo in this area were the local indigenous breeds and therefore they were comparatively low priced. The rate of the livestock was fixed according to their age and sex (Table 3 ).

Table 3. Average farm price of livestock (April, 2018) (Price in NRs)

\begin{tabular}{|l|l|l|l|}
\hline Livestock & $\begin{array}{c}\text { District } \\
\text { Veterinary } \\
\text { Office }\end{array}$ & $\begin{array}{c}\text { Market } \\
\text { Price }\end{array}$ & $\begin{array}{c}\text { Average } \\
\text { Farm- } \\
\text { Price }\end{array}$ \\
\hline Cow-milked & 15000 & 25000 & 20000 \\
\hline OX & 10000 & 20000 & 15000 \\
\hline Young cow & 5000 & 5000 & 5000 \\
\hline Milked buffalo & 50000 & 70000 & 60000 \\
\hline Male buffalo & 15000 & 25000 & 20000 \\
\hline Young buffalo & 10000 & 20000 & 15000 \\
\hline Goat/sheep & 8000 & 12000 & 10000 \\
\hline Pig & 4000 & 6000 & 5000 \\
\hline Dog (local breed) & 0 & 2000 & 2000 \\
\hline
\end{tabular}

The total economic loss by crop depredation was calculated by multiplying the unit rate of the livestock with number of livestock killed by carnivores. Linear regression was used to find out the relation between the distance of the forest and economic loss by crop damage and livestock depredation. Data obtained from the questionnaire were tabulated in tables and presented in bar diagrams, and also analyzed using the PAST version 3.20. software (Hammer et al. 2001).

\section{RESULTS}

\section{Crop damage}

Most of the people around the Panchase area depend upon the agriculture (52\% respondents, Table 1). The agriculture contributes major income source of the farmers. The major crops around Panchase area were paddy, wheat, oat, maize, potatoes and vegetables (Table 4). Besides food grains, horticultural crops i.e., pear, bananas, mangoes were also common in the study area. Northern red muntjac (Muntiacus vaginalis) (Boddaert, 1785), monkey (Macaca mulatta) (Zimmermann, 1780) and Semnopithecus entellus (Dufresne, 1797), porcupine (Hystrix indica) (Kerr, 1792), Indian hare (Lepus nigricollis $\mathrm{F}$.) (Cuvier, 1823) were major wild mammals responsible for crop damage in Panchase. Maize was the major target crops of many wildlife species where monkeys in Panchase area accounted for the highest crop raiding species (Fig. 2).

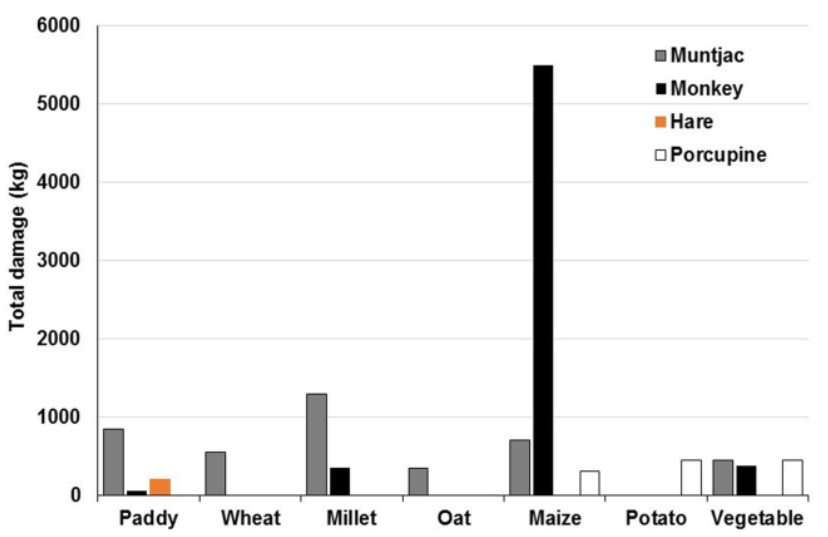

Fig. 2. Crop damage by different wild mammals in Panchase area

The total value of crop yield losses due to damage done by wild mammal in villages around Panchase area was about NRs. 325175 (US\$ 2956.13, US\$ 29.56 per household) in a year (Table 2 and 4). The results show that distance to the forest or wildlife habitats is the major determinant of the intensity of the economic loss due to crop damage by problematic wild mammals. The economic loss was found significantly high near the forest area as compared to area far from forest as shown in Fig. $3\left(F=7.436, r^{2}=0.075, p=0.0075\right)$. 
Table 4. Total economic loss from crop damage by wild mammals in Panchase area (1 US\$ $=$ NRs 110)

\begin{tabular}{|l|l|l|l|}
\hline Crops & $\begin{array}{l}\text { Damge } \\
\text { area in } \\
\text { Ropani } \\
\text { (Ai) }\end{array}$ & $\begin{array}{l}\text { Crop } \\
\text { damge in } \\
\text { Kg (Yi) }\end{array}$ & $\begin{array}{l}\text { Total } \\
\text { economic loss } \\
\text { in NRs (Li) }\end{array}$ \\
\hline Maize & 75.5 & 6510 & 146475 \\
\hline Vegetable & 16.5 & 1280 & 57600 \\
\hline Millet & 19.5 & 1650 & 51150 \\
\hline Paddy & 18 & 1100 & 30250 \\
\hline Wheat & 9 & 550 & 14300 \\
\hline Potato & 7 & 450 & 13500 \\
\hline Oat & 4.5 & 350 & 11900 \\
\hline Total loss economic (NRs) & 69950 \\
\hline Total economic Loss US\$ & 2956.13 \\
\hline Economic loss per HH (US\$) & 29.56 \\
\hline
\end{tabular}

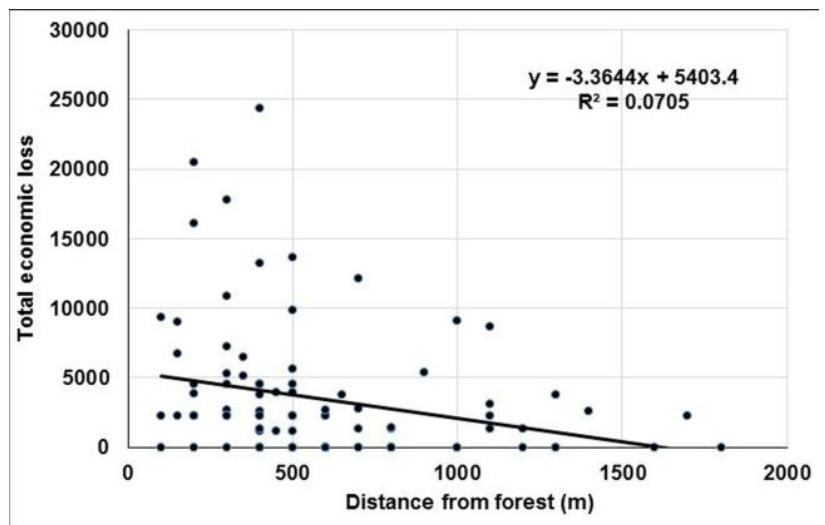

Fig. 3. Relationship between the distance from the forest and economic loss by crop damage

\section{Livestock depredation}

Animal husbandry is the mainstay occupation in the mid hills of CHAL. Majority of people around Panchase area depend on animal husbandry (Table 1). Most of them have own shed and pasture (Kharka) for rotational and free grazing systems (personal communication during field study 2017-18). Hence, most of the calf of the cows, buffalo, goat and sheep will be the target of the predator (Table 5). Leopard killed the highest number of goat and sheep (51.76\%) compared to other livestock like ox/cow $(21.17 \%)$, buffalo $(12.94 \%)$, dog $(10.58 \%)$ and pig $(3.52 \%)$ around the Panchase protected forest. These depredations cost a total value of about NRs. 1238000 (US\$ 11254.54) i.e., US\$ 112.54 per household (Table 3 and 5).

The linear regression analysis to find out the relation between the economic loss by the wild animals and distance from the forest of wildlife habitat showed that rate of livestock depredation was significantly higher near or inside the forest area than the area far from the forest area and hence significantly more economic loss by livestock depredation near the forest area as depicted in Fig. $4\left(\mathrm{~F}=8.292, \mathrm{r}^{2}=0.078, \mathrm{p}=0.004\right)$.

Table 5. Livestock depredation and economic loss in Panchase area

\begin{tabular}{|l|l|l|l|}
\hline Livestock & Number & $\begin{array}{c}\text { Depredation } \\
(\%)\end{array}$ & $\begin{array}{c}\text { Total } \\
\text { economic } \\
\text { loss (NRs) }\end{array}$ \\
\hline Buffalo & 11 & 12.94 & 500000 \\
\hline Goat/sheep & 44 & 51.76 & 440000 \\
\hline Cattle & 18 & 21.17 & 265000 \\
\hline Dog & 9 & 10.58 & 18000 \\
\hline Pig & 3 & 3.52 & 15000 \\
\hline Total economic loss (NRs) & $\mathbf{1 2 3 8 0 0 0}$ \\
\hline \multicolumn{2}{|l|}{ Total economic loss (US\$) } & $\mathbf{1 1 2 5 4 . 5 4}$ \\
\hline \multicolumn{2}{|l|}{ Economic loss per house hold (US\$) } & $\mathbf{1 1 2 . 5 4}$ \\
\hline
\end{tabular}

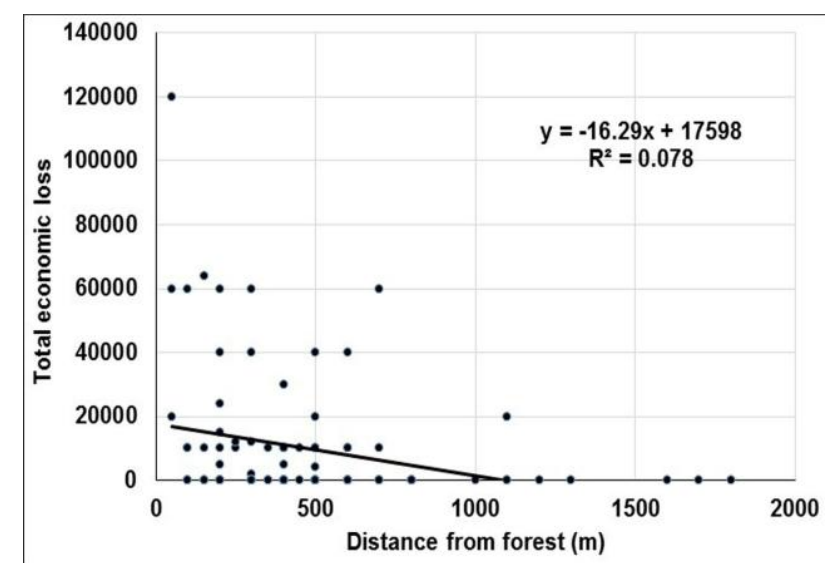

Fig. 4. Relationship between the distance from the forest and economic loss by livestock depredation

\section{Human casualty and injury}

In general, attacks by wildlife were significantly associated with the location where the people interact with natural resources (forest), farmland and home. All attacks of wildlife to people were inside the forest or nearby the forests (personal communication). A total of five cases of attack (4 injuries and 1 fatal) were recorded from Panchase area. Among these cases, Himalayan black bear contributed $80 \%$ of the total attacks and $20 \%$ attack was contributed by leopard (Table 6).

\section{Human wild mammals conflict hotspots}

Human wild mammal conflict was very common in and around the Panchase protected forest area. Results showed Sidhane area possessed the highest economic loss of NRs 437550 due to conflict followed by Panchase Bhanjyang area (NRs 343300), Arthar Dada (NRs 196350), Bhadaure (NR. 151500), Chitre (NRs 91750) and the least in Pumdi Bhumdi area (NRs 87500). However, other areas possessed less economic loss due to wild mammals. 
Table 6. Human fatalities and injury by mammals (number in the bracket indicate fatal cases)

\begin{tabular}{|l|c|c|}
\hline Mammals & $\begin{array}{c}\text { Contribution } \\
(\mathbf{\%})\end{array}$ & $\begin{array}{c}\text { Number of Attack } \\
\text { in 2017/18 }\end{array}$ \\
\hline $\begin{array}{l}\text { Mountain } \\
\text { black bear }\end{array}$ & 80 & $4(1)$ \\
\hline Leopard & 20 & $1(0)$ \\
\hline
\end{tabular}

\section{DISCUSSION}

To identify the pattern of HWC and evaluate the major causes of the conflicts are important components of conservation biology. This study shed light on the pattern of crop damage, livestock depredation and human death and injury caused by wild mammals in Panchase area. Muntjac deer, monkeys, porcupines were top crop depredators whereas, leopard was main livestock depredators. For the kill/injury ratio, Himalayan black bear ranked the highest, followed by leopard. From the field study and local people, the number of wildlife had increased after the establishment of Panchase protected area and community forest. Similar to our study, many research have suggested that human-tiger conflicts, human elephant conflicts, human rhinoceros conflicts and human herbivores (Chital) were very common in Terai and human-bear, human-leopard conflicts, human-monkey conflicts and human herbivore conflicts are the most serious human-wildlife conflicts in mid-hills and high mountains of Nepal (Srivastava \& Begum 2005, Inskip \& Zimmermann 2009, Aryal et al. 2010, Bista \& Aryal 2013, Adhikari et al. 2018b). However, the majority of issues of conflicts occurred in human-dominated landscapes (i. e, mid-hills), that highlights the need for proper conservation management outside Protected areas (Lamichhane et al. 2018).

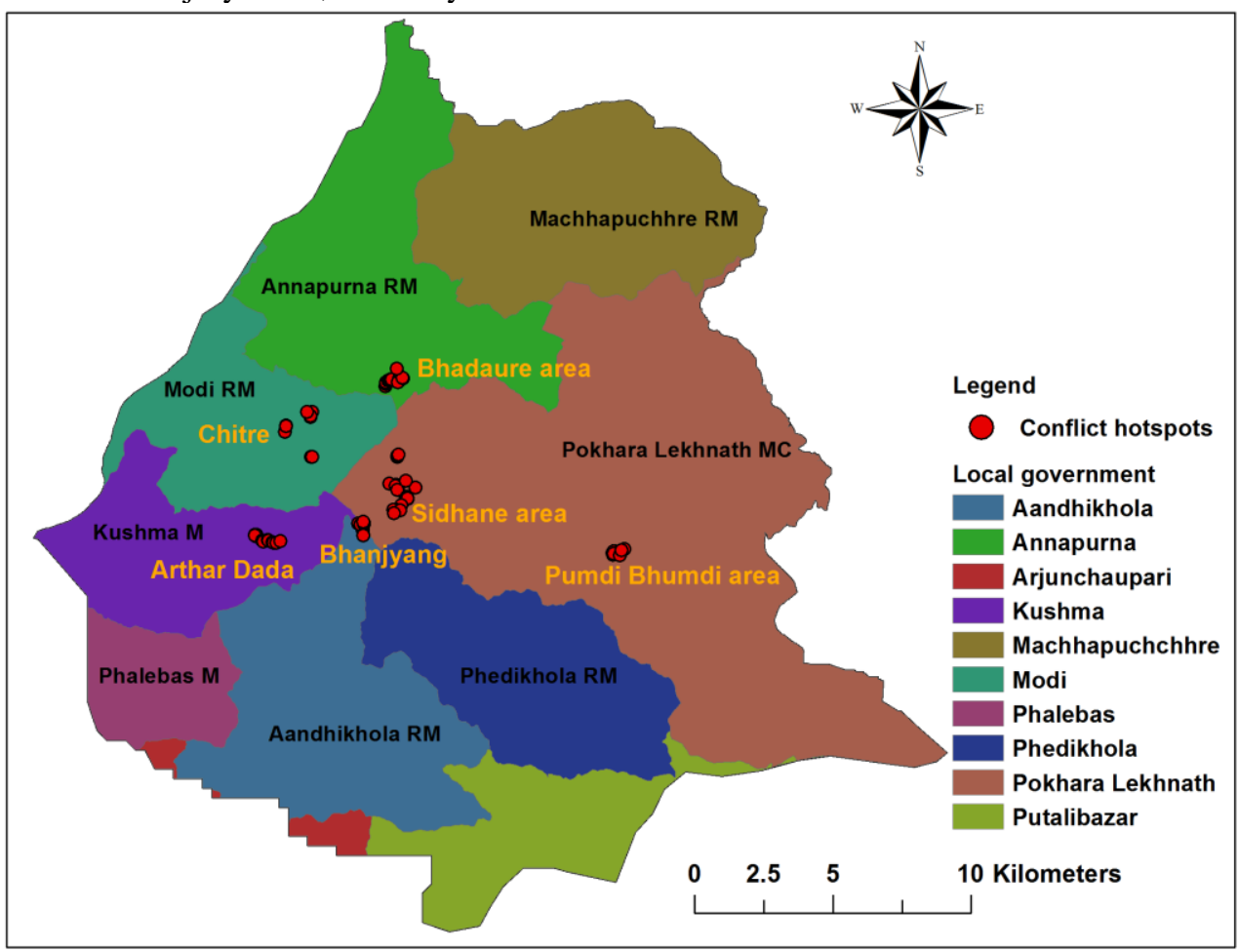

Fig. 5. Hotspots of human wild mammal conflict in and around the Panchase Protected Forest (RM- rural municipality, M- municipality, MC- metropolitan city)

Primates, mainly Rhesus macaques and Hanuman langur are pest species that share food and space with humans in the rural and urban areas and are also known to cause suffering and economic loss by means of crop raiding and robbing and attacks on human (Lamichhane et al. 2018, Bhattarai \& Rijal 2018). The people of Panchase area were also suffering from such problems from monkeys that created highest crop damage (mainly maize) and economic loss. Muntjac deer among the ungulates was the main crop raider (Fig. 2).
Some villages of Panchase are located inside the forest areas and there was no electric or mesh fencing for controlling the crop damage. Similar type of study conducted by IUCN (2014) in Panchase and associated area found that crop damage was the most widespread with estimated average economic loss of US\$ 150 per household. Currently, the crop damage rate has reduced (US\$ 29.56 per $\mathrm{HH}$ ), as some people left the land for cropping due to migration to city area for better life. 
Animal husbandry and agriculture are important part of household's livelihoods and incomes in human dominated mid-hills that creates competition between local communities and wildlife for the use of natural resources, that creates escalating conflict (Bayani et al. 2016). Total loss of livestock predation per household in ACA at US \$ 95 in 2009 and US\$ 42 in 2010, with leopards blamed for $94.9 \%$ of the losses (Koirala et al. 2012). Similarly, loss of livestock to carnivores caused more than two third villagers annual income in the Jigme Singye Wanhchuck National Park, Bhutan, with leopards blamed for $53 \%$ of the losses (Wang et al. 2006). Leopard caused substantial economic damage to the rural people (Lamichhane et al. 2018, Bhattarai \& Rijal 2018). Such type of loss was found in the Panchase area, where leopard contributed $100 \%$ of livestock depredation with the loss of US\$ 112.54 per household. Such type of study conducted by different researchers also indicated that increasing tiger population within a protected area was correlated to higher incidences of livestock depredation outside the protected area by leopards (Harihar et al. 2011, Thapa 2011). This study showed that livestock depredation was significantly higher near to the forest area (Figs 3 and 4). This study also showed that human-dominated landscapes (e.g., Panchase) and not PAs were the major wildlife conflict hotspots in Nepal.

A total of five cases of attack were recorded from Panchase area. Among these cases, Himalayan black bear contributed $80 \%$ of the total attacks and $20 \%$ attack was contributed by leopard (Table 6). The progress report from 2005 to 2013 of NTNC (2013) found that six cases of Himalayan black bear attack were noted in various locations of Manaslu Conservation Area, Nepal. Thapa (2014) reported that at least 137 persons were attacked and 40 were killed by leopard in Nepal during 2006 to 2013. Similarly, 45 individuals were attacked and 14 were killed in Chitwan Annapura Landscape (CHAL). The study in different parts of mountain area of world concluded that Himalayan black bear and leopard were the major mammals responsible for human attack (Bhatia et al. 2013, Kabir et al. 2014, Constant et al. 2015). The carnivore people conflict is high in areas where natural prey base is low and high human disturbance in their natural habitats as observed in the CNP (Bhattarai \& Kindlmann 2013, 2018). The widespread common leopard and Himalayan black bear caused conflicts along the entire mid-hills of Nepal far from the PAs (Koirala et al. 2012, Bista \& Aryal 2013, Atreya et al. 2015). But district forest offices have no institutional capacity for capturing and handling the leopard and Himalayan black bear, and monitoring of the other wildlife species in regular basis. Hence, we suggest that there is an urgent need to train the staffs to address the issues of conflicts and animal handling. This study focused only the issues and status of conflicts in the Panchase area, a representative of midhills and Chitwan Annapurana Landscape that directly and indirectly affect the landscape change. Thus, recommends that future study should be conducted to highlight the mitigation and preventing methods to minimize the issues of human wildlife conflicts.

\section{CONCLUSION}

Crop damage by ungulates and primates, livestock depredation by leopard and human injury and casualties by Himalayan black bear and leopards were the common issues of conflict in Panchase area. The maize was the predominant crop (total loss: $6510 \mathrm{~kg}$ ). The total economic loss from the crop damage was US\$ 2956.13 (US\$ 29.56/HH). The frequency of the crop damage and livestock depredation was significantly higher near the forest area. Leopard alone contributes $100 \%$ of livestock depredation causing US\$ 112.54/HH economic loss. Goat and sheep, cow, calf of buffalo were the main target of leopard. A total of five human attacks (one fatal, four injuries) have been recorded. Eighty percent of the total attacks were contributed by Himalayan black bear and 20 $\%$ by leopard. This study focused on the major issues and status of human wildlife conflicts in Panchase area, a part of the Chitwan Annapurna Landscape. Further study about the mitigation and control measures of human wildlife conflict is recommended for future in mid-hills.

\section{ACKNOWLEDGEMENTS}

We would like to thank the District Forest Office, Kaski and Panchase Protected Forest Management Committee for granting permission to conduct the research work. We also extent our thanks to USAID funded Hariyo Ban Program, WWF Nepal for granting the PhD Research Grants. Our thanks also go to people of Panchase area who supported and provided the information about issues of human wild mammals' conflicts

\section{REFERENCES}

Adhikari, B., Pendry, C. Måren, I., Bhattarai, K. and Chaudhary, R. 2017. Distribution and preliminary conservation assessments of commonly used forest species in the Nepalese Himalayas. Banko Janakari 27: 43-54.

Adhikari, S., Baral, H. and Nitschke, C. 2018a. Adaptation to climate change in Panchase Mountain ecological regions of Nepal. Environments 5: 42.

Adhikari, K., Khanal, L. and Chalise, M.K. 2018b. Status and effects of food provisioning on ecology of assamese monkey (Macaca assamensis) in Ramdi area of Palpa, Nepal. Journal of Institute of Science and Technology 22: 183-190.

Amaja, L.G., Feyssa, D.H. and Gutema, T.M. 2016. Assessment of types of damage and causes of humanwildlife conflict in Gera district, south western Ethiopia. Journal of Ecology and the Natural Environment 8: 49-54. 
Aryal, A., Sathyakumar, S. and Schwartz, C.C. 2010. Current status of brown bears in the Manasalu Conservation Area, Nepal. Ursus 21: 109-114.

Atreya, A., Kanchan, T. Nepal, S. and Acharya, J. 2015. Brown bear attacks in a Nepalese scenario: a brief review. Wilderness \& Environmental Medicine 26: $587-588$

Baral, S., Adhikari, A., Khanal, R., Malla, Y., Kunwar, R., Basnyat, B., Gauli, K. and Acharya, R. 2017. Invasion of alien plant species and their impact on different ecosystems of Panchase Area, Nepal. Banko Janakari 27: 31-42.

Bayani, A., Tiwade, D., Dongre, A., Dongre, A.P., Phatak, R. and Watve. M. 2016. Assessment of crop damage by protected wild mammalian herbivores on the western boundary of Tadoba-Andhari tiger reserve (TATR), central India. PloS one 11: $\mathrm{e} 0153854$

Bhatia, S., Athreya, V., Grenyer, R. and Macdonald, D.W. 2013. Understanding the role of representations of human-leopard conflict in Mumbai through mediacontent analysis. Conservation Biology 27:588-594.

Bhattarai, K., Måren, I. and Chaudhary, R. 2011. Medicinal plant knowledge of the Panchase region in the middle hills of the Nepalese Himalayas. Banko Janakari 21: 31-39.

Bhattarai, B.P. and Kindlmann, P. 2013. Effect of human disturbance on the prey of tiger in the Chitwan National Park - implications for park management. Journal of Environmental Management 131: 343350 .

Bhattarai, B.P. and Kindlmann, P. 2018. Human disturbance is the major determinant of the habitat and prey preference of the Bengal tiger (Panthera tigris tigris) in the Chitwan National Park, Nepal. European Journal of Ecology 4(1): 13-21.

Bhattarai, B.P. and Rijal, M.K. 2018. Human-wildlife conflict and people's perception towards wildlife conservation in Chitwan National Park, Nepal. Proceedings of the Nature Research Society, in press.

Bista, R. and Aryal, A. 2013. Status of the Asiatic black bear Ursus thibetanus in the southeastern region of the Annapurna conservation area, Nepal. Zoology and Ecology 23: 83-87.

Constant, N., Bell, S. and Hill, R. 2015. The impacts, characterisation and management of human-leopard conflict in a multi-use land system in South Africa. Biodiversity and Conservation 24: 2967-2989.

Cromsigt, J.P., Kuijper, D.P., Adam, M., Beschta, R.L., Churski, M., Eycott, A., Kerley, G.I., Mysterud, A.,
Jagan Nath Adhikari, Bishnu Prasad Bhattarai, Tej Bahadur Thapa

Schmidt, K. and West, K. 2013. Hunting for fear: innovating management of human-wildlife conflicts. Journal of Applied Ecology 50: 544-549.

Dhungana, R., Savini, T. Karki, J.B. and Bumrungsri, S. 2016. Mitigating human-tiger conflict: an assessment of compensation payments and tiger removals in Chitwan National Park, Nepal. Tropical Conservation Science 9: 776-787.

Fernando, P., Wikramanayake, E. Weerakoon, D. Jayasinghe, L., Gunawardene, M. and Janaka, H. 2005. Perceptions and patterns of human-elephant conflict in old and new settlements in Sri Lanka: insights for mitigation and management. Biodiversity \& Conservation 14: 2465-2481.

Hammer, Ø., Harper, D.A.T. and Ryan, P.D. 2001. PAST: Paleontological statistics software package for education and data analysis. Palaeontologia $\begin{array}{lll}\text { Electronica } & \mathbf{4}(1): & 9 \mathrm{pp} .\end{array}$ https://folk.uio.no/ohammer/past/

Harihar, A., Pandav, B. and Goyal, S.P. 2011. Responses of leopard Panthera pardus to the recovery of a tiger Panthera tigris population. Journal of Applied Ecology 48: 806-814.

Inskip, C., and Zimmermann, A. 2009. Human-felid conflict: a review of patterns and priorities worldwide. Oryx 43: 18-34.

IUCN. 2014. A report on human wildlife conflict: In Panchase area, juncture of Kaski, Parbat and Syangja diatricts. IUCN Nepal, pp. 88.

Kabir, M., Ghoddousi, A. Awan, M.S. and Awan, M.N 2014. Assessment of human-leopard conflict in Machiara National Park, Azad Jammu and Kashmir, Pakistan. European Journal of Wildlife Research $\mathbf{6 0}$ 291-296.

Koirala, R.K., Aryal, A., Amiot, C. Adhikari, B. Karmacharya, D. and Raubenheimer, D. 2012. Genetic identification of carnivore scat: implication of dietary information for human-carnivore conflict in the Annapurna Conservation Area, Nepal. Zoology and Ecology 22: 137-143.

Lamichhane, B.R., Persoon, G.A., Leirs, H., Poudel, S. Subedi, N., Pokheral, C.P., Bhattarai, S., Thapaliya, B.P. and De Iongh, H.H. 2018. Spatio-temporal patterns of attacks on human and economic losses from wildlife in Chitwan National Park, Nepal. PloS one 13: e0195373.

Lamsal, S. 2012. The park-people conflict in the Chitwan National Park with reference to the Asiatic onehorned rhinoceros (Rhinoceros unicornis). Institutt for biologi. 
Madden, F., and McQuinn, B. (2014). Conservation's blind spot: the case for conflict transformation in wildlife conservation. Biological Conservation 178: 97-106.

Måren, I.E., Bhattarai, K.R. and Chaudhary, R.P. 2014. Forest ecosystem services and biodiversity in contrasting Himalayan forest management systems. Environmental Conservation 41: 73-83.

Messmer, T.A. 2009. Human-wildlife conflicts: emerging challenges and opportunities. Human-Wildlife Conflicts 3: 10-17.

Mwamidi, D.M., Renom, J.G., Fernández-Llamazares, Á., Burgas, D., Domínguez, P. and Cabeza, M. 2018. Contemporary pastoral commons in east africa as oecms: a case study from the daasanach community. Parks 24: 79.

Nepal, W. 2007. A Case Study on Human-Wildlife Conflict in Nepal. World Wildlife Fund, Kathmandu, Nepal

NTNC. 2013. Distribution and abundance of Himalayan black bear and brown bear and human-bear bonflict in Manaslu Conservation Area, Nepal. Report submitted to Taronga Conservation Society, Australia.

Ogutu, J.O., Reid, R.S., Piepho, H.P., Hobbs, N.T., Rainy, M.E., Kruska, R.L., Worden, J.S. and Nyabenge, M. 2014. Large herbivore responses to surface water and land use in an East African savanna: implications for conservation and human- wildlife conflicts. Biodiversity and Conservation 23: 573-596.

Park, J. and Alam, M. 2015. Ecosystem-based adaptation planning in the Panchase mountain ecological region. Hydro Nepal: Journal of Water, Energy and Environment 17: 34-41.

Redpath, S.M., Bhatia, S. and Young, J. 2015. Tilting at wildlife: reconsidering human-wildlife conflict. Oryx 49: $222-225$

Srivastava, A. and Begum, F. 2005. City monkeys (Macaca mulatta): a study of human attitudes. Commensalism and conflict, The human-primate interface 258-269.

Thapa, T.B. 2011. Habitat suitability evaluation for Leopard (Panthera pardus) using remote sensing and GIS in and around Chitwan National Park, Nepal. $\mathrm{PhD}$ Thesis, Saurashtra University, India.

Thapa, T.B. 2014. Human caused mortality in the Leopard (Panthera pardus) population of Nepal. Journal of Institute of Science and Technology 19: 155-150.

Upreti, B. 1985. The park-people interface in Nepal: problems and new directions. In: Proceeding of international workshop on the management of National Parks and protected areas in the Hindu Kush-Himalaya. KMTNC and ICIMOD, Kathmandu.

Wang, S.W., Lassoie, J.P. and Curtis, P.D. 2006. Farmer attitudes towards conservation in Jigme Singye Wangchuck National Park, Bhutan. Environmental Conservation 33: 148-156. 